\title{
Yangın Alanında Uydu Görüntüleri ile Yer Yüzey Sıcaklık Değişimi Gözlemi ve Mekânsal Alan Tespiti
}

\author{
Alperen Cihan $^{1, *}{ }^{*}$, Kübra Cerit $^{1} \oplus$, Arzu Erener ${ }^{1} \oplus$ \\ ${ }^{1}$ Kocaeli Üniversitesi, Mühendislik Fakültesi, Harita Mühendisliği, 41380, Kocaeli.
}

\section{Özet}

Ormanların kaybını önlemek amacıyla yangınlarla mücadele son derece önemli bir problemdir. Gelișen teknolojiyle birlikte zaman içerisinde uydu görüntüleri yanginlarla mücadelede için temel gereçlerden biri haline gelmiştir. Çeşitli indeksler kullanılarak, görüntü ișleme analizleri ve yüzey sicaklık analizleri ile uydu görüntüleri üzerinden yanan alanın tespitini yapmak mümkündür. Yersel ölçümlerle yapılan yöntemlerin aksine oldukça hızlı ve nispeten daha az maliyetlidir. Bu çalışmada Landsat-8 uydu görüntüleri kullanılarak 1 Temmuz 2017'de İzmir ili Menderes ilçesinde gerçekleşen ve yaklaşı 67 saat süren Deliömerli orman yangını analiz edilmiştir. Yangın öncesi ve yangın anı için elde edilen görüntülerden yer yüzey sıcaklık haritaları oluşturularak, farklı arazi kullanımları için yüzey sıcaklık farklılıkları incelenmiştir. Buna göre yangın anında yanan alanın yüzey sıcaklı̆̆ının diğer arazi kullanım alanlarına göre arttığı gözlemlenmiştir. Yangın alanı tespitinde ise üç farklı yöntem kullanılıp yangın alanı mekânsal büyüklüğü karşılaştırılmıştır. Bu kapsamda Normalize Edilmiş Bitki Örtüsü İndeksi (NDVI) ile 1.235 hektar alanın, Normalize Edilmiş Yanma Şiddeti (NBR) indeksleri ile 1.221 hektar alanın ve sınıflandırma çalıșması sonrası ise 1.296 hektar alanın yandığ tespit edilmiştir. Sonuçların Orman Genel Müdürlügü tarafindan açıklanan hasar tespit sonuçları ile tutarlı olduğu gözlenmiştir. CORINE arazi kullanım haritası ve yanan alanlar örtüş̧ürülerek yangın sonucunda arazi kullanım sinıflarının yangından ne kadar etkilendiği incelenmiştir. Yapılan örtüşme analizi sonucunda yanan alanın \%75,7'sinin iğne yaprakl ormanlar, \%19,3'ünün bitki alanları, $\% 4,2$ 'sinin karışık ormanlar ve \%0,7'sinin tarım alanları olduğu tespit edilmiştir.

\section{Anahtar Sözcükler}

Yer Yüzey Sıcaklığı, NDVI, NBR, Sınıflandırma, Orman Yangını, Landsat

\section{Land Surface Temperature Change Observation and Spatial Area Determination with Satellite Images in the Fire Area}

\begin{abstract}
Fighting fires is an extremely important issue to prevent the loss of forests. With the developing technology, satellite images have become one of the basic tools for fighting fire over time. By using various indexes, it is possible to detect the burning area from satellite images with image processing analysis and surface temperature analysis. Unlike the methods made by ground measurements, it is very fast and relatively less costly. In this study, the Deliömerli forest fire that took place in Menderes district of Izmir province on July 1 , 2017, and lasted about 67 hours was analyzed using Landsat-8 satellite images. The surface temperature maps were created from the images obtained before and during the fire, and surface temperature differences were examined for different land uses. Accordingly, it has been observed that the surface temperature of the area burning during the fire increased compared to other land use areas. In determining the fire area, three different methods were used and the spatial size of the fire area was compared. In this context, 1,235 hectares with Normalized Difference Vegetation Index (NDVI), 1,221 hectares with Normalized Burn Ratio (NBR) indices, and 1,296 hectares with the classification study were determined to be burned. It has been observed that the results are consistent with the damage assessment results announced by the General Directorate of Forestry. The burning areas were overlapped with the CORINE land use map and the extent of the impact of the fire on each land use class was examined. As a result of the overlap analysis, it was determined that $75.7 \%$ of the burning area was coniferous forests, $19.3 \%$ plant areas, $4.2 \%$ mixed forests and $0.7 \%$ agricultural areas.
\end{abstract}

$\underline{\text { Keywords }}$

Land Surface Temperature, NDVI, NBR, Classification, Forest Fire, Landsat

\section{Giriş}

Orman yangınları, etkileri ve sonuçları açısından bütün ülkeleri ilgilendiren afetlerin en önemlilerinden biridir. Yangınlar sonucunda dünya genelinde her yıl milyonlarca hektar orman alanı zarar görmektedir. . Büyük çapta yangınla mücadele masrafına ve ormanların bazı fonksiyonlarının yok olmasına sebep olmaktadır. İnsanoğlu çeşitli ihtiyaçlarını karşılamak amacıyla doğal bir kaynak olan ormanlara sık sık başvurmaktadır.

\footnotetext{
* Sorumlu Yazar: Tel: +90 (262) 3033002 Fax: +90 (262) 3033003

E-posta: alperencihan@outlook.com (Cihan A), kubracerit74@gmail.com (Cerit K) erener.arzu@gmail.com (Erener A)
}

Gönderim Tarihi / Received : 25/05/2021 
Özellikle yangınlar Türkiye'de ormanların yaşamını tehdit eden etkenlerin başında gelmektedir. Türkiye'nin önemli bir bölümü, Akdeniz iklimi etkisi altındadır. Bu iklim orman yangınları açısından en elverişli koşullara sahip olan iklimdir. Bu sebeple Türkiye sürekli olarak orman yangını tehlikesi ile karşı karşıyadır. Çalışma kapsamında incelenecek Menderes Deliömerli yangının gerçekleştiği sene olan 2017 yılı içinde Türkiye'de 2.411 adet orman yangını gerçekleşmiş, bu yangınlar sonucunda 11.993 hektar orman alanı zarar görmüştür.

Yangınlarla ilgili parametrelerin yersel ölçümler kullanılarak yapılması oldukça maliyetlidir. Bunun yanında yoğun miktarda insan gücü ve uzun zaman harcamak gerekmektedir. Zaman, bir yangın söz konusu olduğunda kritik önem taşımaktadır (Yavuz ve Sağlam 2011). Bütün bu etkenler göz önüne alındığında, uzaktan algılama sistemleri kurtarma veya araştırma çalışmalarında kullanılabilecek önemli bir kaynak oluşturmaktadır.

Tekeli vd. (2007) tarafından yapılan çalışma sonucunda uzaktan algılama kullanılarak yapılan çalışmalarla insan faktörünün en aza indirilebileceği, böylece sürekli ve tutarlı veri setlerinin elde edilmesinin daha mümkün olacağ kanısına varılmıştır. Yavuz ve Sağlam (2011) yaptıkları çalışmada uzaktan algılama ve coğrafi bilgi sistemleri teknolojilerinin olası yangın tehdidinin belirlenmesi, yangın davranışlarının gözetlenmesi ve yangın sonrasında yapılacak hasar tespit ve analiz çalışmalarındaki rolü üzerinde durmuştur. Bu teknolojilerin getirdiği kolaylıklar incelenmiştir. Gürkan vd. (2016), kontrollü sınıflandırma ve adımlarını detaylı bir şekilde ele almış, Worldview uydu görüntülerine uygulayarak Mustafa Kemal Üniversitesi Tayfur Ata Sökmen Yerleşkesinin arazi kullanım haritasını oluşturmuştur. Sabuncu ve Özener (2019) tarafından ortaya koyulan çalışmada uzaktan algılama teknikleri ile İzmir Seferihisar orman yangınının analizi yapılmıştır. Landsat-5 uydu görüntüleri kullanılarak NDVI (Normalized Difference Vegetation Index) ve NBR (Normalized Burn Ratio) indeksleri hesaplanmıştır. Ayrıca maksimum benzerlik algoritması uygulanarak piksel tabanlı kontrollü sınıflandırma işlemi gerçekleştirilmiştir. Bu indeksler kullanılarak yanarak tahrip olmuş alan tespit edilmiştir.

Orhan vd. (2019), Landsat-5 gerçek zamanlı infrared termometre ölçümleri ile Konya kapalı havzasında sıcaklık değişimini ölçmüştür. Yer yüzey 1Sı haritaları 1984 ve 2011 yılları arasındaki farklılığı gözlemlemek amacı ile oluşturulmuş ve yaklaşık $20^{\circ} \mathrm{C}$ fark tespit edilmiştir. Quintanoa vd. (2014), yaptıkları çalışmada "Yeşil İspanya" olarak da bilinen İspanya'nın kuzey-batı bölgesinde, 19-21 Eylül 2012 tarihleri arasında gerçekleşen yangının yer yüzey sıcaklığı üzerindeki etkisi incelenmiştir. İnceleme doğrultusunda Landsat-7 verileri kullanılmıştır. Bu kapsamda 6 farklı zamana ait uydu görüntüsü üzerinden meydana gelen etkiler incelenmiştir. Yapılan incelemede yanan bölgelerin, yangından etkilenmeyen bölgelere göre $15,5^{\circ} \mathrm{C}, 12,7^{\circ} \mathrm{C}, 6,8^{\circ} \mathrm{C}, 11,4^{\circ} \mathrm{C}, 14,2^{\circ} \mathrm{C}$ ve $12,4^{\circ} \mathrm{C}$ derece daha yüksek yer yüzey sıcaklıklarına sahip olduğu tespit edilmiştir. Vlassova vd. (2014), yaptıkları çalışmada 2009 yılında İspanya'nın Extremadura bölgesinde meydana gelen Las Hurdes yangınının yer yüzey sicaklığı değişimlerini incelemiştir. Bu çalışmada yangın sonrasında 27 aylık süreci kapsayan 15 adet Landsat-5 uydu görüntüsü analiz edilmiştir. Analiz tek pencere algoritması kullanılarak gerçekleştirilmiştir. Yer yüzey sıcaklığı analizi sonucunda yangın bölgesinde ortalama sıcaklık artış1 $13^{\circ} \mathrm{C}$ olsa da, yer yer sıcaklık artışının $20^{\circ} \mathrm{C}$ 'ye kadar yükseldiği tespit edilmiştir. Erener ve Sarp (2017) yaptıkları çalışmada, Antalya'nın Manavgat bölgesinde 2008 yılında çıkan dört farklı yangını bilgi teknolojileri kullanarak incelemiştir. Bu çalışmada uydu görüntü analizlerinin yangın alanı tespitinde oldukça kullanışlı olduğu sonucuna varılmıştır. Sarp vd. (2018), yaptıkları çalışmada 1 Temmuz 2017 tarihinde Mersin ili Anamur ilçesi Yukarıkükür mahallesi mevkiinde gerçekleşen ve 200 hektar alanın zarar görmesiyle sonuçlanan yangını uzaktan algılama teknikleri kullanılarak analiz etmiş, yangının yüzey nemliliği ve yer yüzey sıcaklıkları üzerindeki etkisini Landsat-8 uydu görüntülerini kullanarak değerlendirmiştir. Çalışma sonucunda yangın öncesinde $8,69^{\circ} \mathrm{C}$ ile $37,03^{\circ} \mathrm{C}$ arasında değişim gösteren yangın bölgesinin, yangın sonrasında $25,50^{\circ} \mathrm{C}$ ile $49,79^{\circ} \mathrm{C}$ arasında değerler aldı ̆̆ tespit edilmiştir. Taşdelen (2019) yapmış olduğu yüksek lisans çalışmasında ve Taşdelen ve Erener (2019) tarafından yapılan çalışmada, MODIS (Moderate Resolution Imaging Spectroradiometer) verilerini kullanarak ülke ölçeğinde 2000-20052010-2017 yılları için mevsimsel olarak Yer Yüzey Sıcaklığı (YYS) analizleri yapmış, bu analizleri zamansal olarak karşılaştırmıştır. Landsat-5 ve Landsat-8 uydu görüntülerini kullanarak Kocaeli il sınırları için YYS haritaları oluşturmuştur. Toprak, şehir, bitki, su gibi farklı arazi kullanım sınıfları için sıcaklık değerlerini incelemiştir. Kocaeli ilinin YYS analizlerini mevsimsel ve yıllık ortalama olacak şekilde karşılaştırmıştır. Akyürek (2020) tarafından yapılan çalışmada, Landsat-8 uydu görüntüleri kullanılarak Kocaeli ilinin 2015-2019 yılları arasında temmuz ayına ait YYS analizleri yapılmış ve haritaları çıkarılmıştır. Kocaeli'de sanayileşmenin yüksek olduğu batı bölgelerinde ve jeotermal aktivitenin yüksek olduğu güney bölgelerinde YYS değerlerinin yüksek olduğu gözlenmiştir. Mercan (2020) çalışmasında, Landsat-5 ve Landsat-8 uydu görüntüleri kullanarak Muş ilinin 29 yıllık YYS değişimi analizlerini yapmış, 1990-2000-2005-2011-2019 yıllarına ait YYS haritaları üretmiştir. Polat (2020) çalışmasında Mardin şehrinin 29 yıllık yer yüzey sıcaklık değişimi haritalarını hazırlamıştır.

$\mathrm{Bu}$ çalışmanın amacı uydu görüntüleri kullanılarak 2017 yılında yaşanan İzmir Menderes Deliömerli Mahallesi yangınının sebeplerinin bitki örtüsü ve toprak kullanımı dikkate alınarak incelenmesi, yer yüzey sıcaklığı değişiminin analiz edilmesi, çeşitli indeksler kullanılarak yanmış bölgenin tespitinin alansal olarak yapılmasıdır.

\section{Yöntem}

Büyük yangın sınıfına giren, İzmir'in Menderes ilçesinin Deliömerli Mahallesi’nde çıkan orman yangını örnek alan olarak seçilmiştir. Yapılan çalışmanın akış şeması Şekil 1'de gösterilmektedir. 


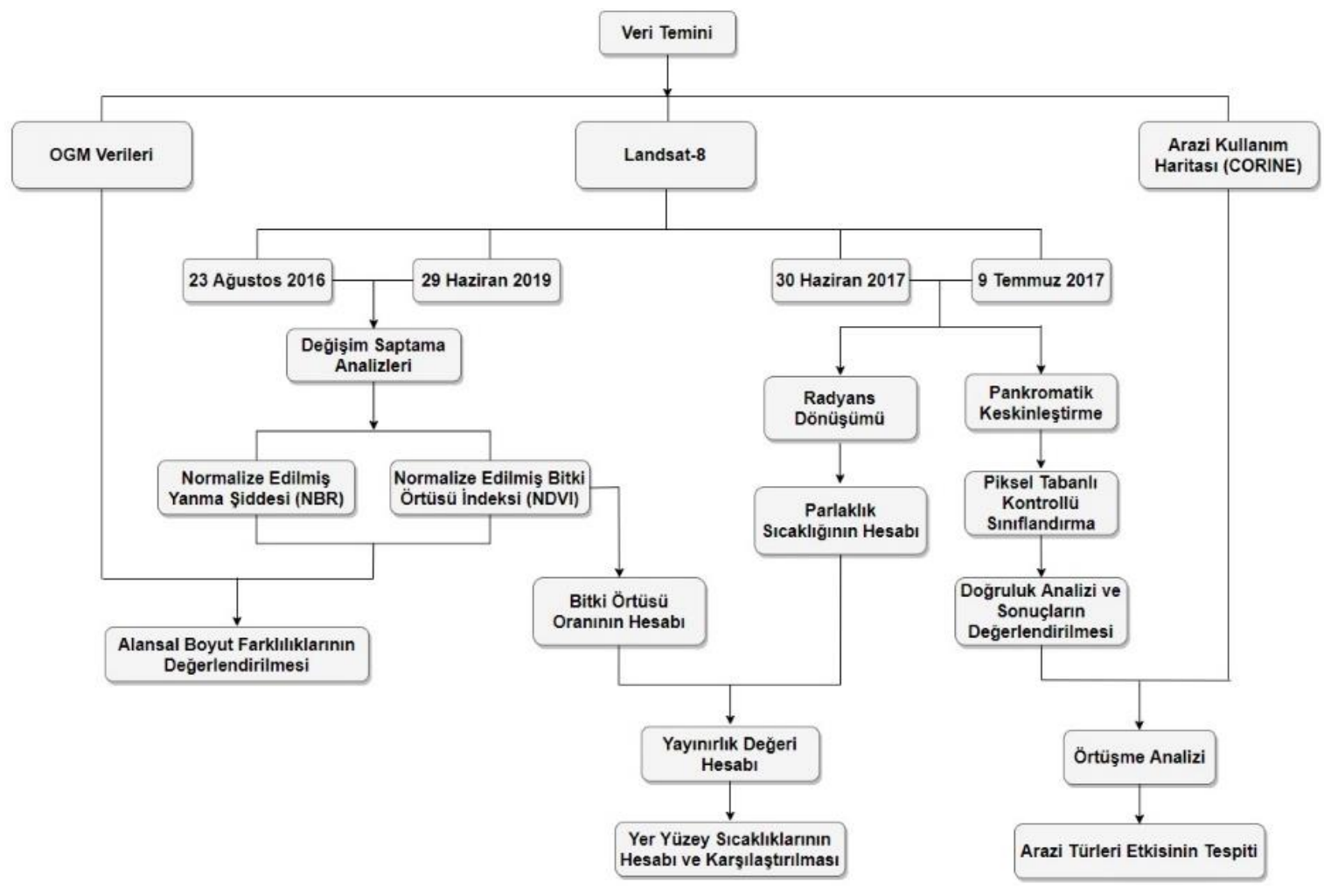

Şekil 1: Çalışma sırasında izlenen işlem adımları

Çalışmada ilk olarak veri temini yapılmıştır. Yanan alanın hasar tespitine yönelik veriler ve çalışmada kullanmak üzere bazı istatistiksel veriler Orman Genel Müdürlüğ̈̈’nün sitesinden (ogm.gov.tr), bölgenin hava durumuna ve iklim özelliklerine ait bilgiler ise Meteoroloji Genel Müdürlüğü’nün sitesinden (mgm.gov.tr) ve havaizleme.gov.tr üzerinden ücretsiz olarak elde edilmiştir. Uydu görüntüleri United States Geological Survey (earthexplorer.usgs.gov) üzerinden, arazi kullanım haritası ise Copernicus Land Monitoring Service (land.copernicus.eu) üzerinden ücretsiz bir şekilde indirilmiştir.

Veriler elde edildikten sonra Landsat-8 uydu görüntülerine pankromatik keskinleştirme işlemi uygulanmıştır. Keskinleştirme yöntemi, yüksek çözünürlüğe sahip siyah-beyaz Pan bandı ile düşük mekânsal çözünürlüğe sahip multispektral bantların füzyonu ile yüksek çözünürlüklü renkli görüntüler elde edilmesini sağlamaktadır (Zhang, 2002). Keskinleştirme işlemi aynı sensördeki bantları ya da farklı sensördeki bantları kullanarak yapılabilir. Bu çalışma kapsamında işlem 2 numaralı mavi bant, 3 numaralı yeşil bant, 4 numaralı kırmızı bant ve 8 numaralı pankromatik bant kullanılarak gerçekleştirilmiştir. Termal bant kullanılarak yangın öncesi ve sonrası için yer yüzey sıcaklığı analizi gerçekleştirilmiş̧ir. CORINE arazi kullanım sınıfları için karşılaştırma grafikleri oluşturularak sıcaklık farklılıkları yorumlanmış ve korelasyon değerleri hesaplanmıştır. Uydu görüntüleri üzerinden yanan alanının hasar tespitini yapmak amacıyla 3 farklı uzaktan algılama analiz yöntemi kullanılmıştır. Kullanılan yöntemler normalize edilmiş bitki örtüsü indeksi (NDVI), normalize edilmiş yanma şiddeti (NBR) ve piksel tabanlı kontrollü sınıflandırmadır. Bu yöntemler, verdiği sonuçlar da göz önüne alınarak birbirleriyle karşılaştırılmıştır. Landsat-8 uydu görüntülerinin dördüncü, beşinci ve yedinci bantları kullanılarak NDVI ve NBR, pankromatik keskinleștirme uygulanmış olan uydu görüntüleri kullanılarak ise maksimum olabilirlik yöntemiyle piksel tabanlı kontrollü sınıflandırma işlemi Arcmap üzerinden yapılarak yanan alan tespiti yapılmıştır. İşlemler sonucunda tespit edilen sonuçlar Orman Genel Müdürlüğü (OGM) tarafından açıklanan hasar tespit sonuçları ile karşılaştırılmış ve alansal boyut farklılıkları değerlendirilmiştir. Google Earth üzerinde atılan 446 adet referans noktası Arcmap'e aktarılarak piksel tabanlı kontrollü sınıflandırma işlemi için doğruluk analizi yapılmıştır. Bulunan sonuçlar değerlendirilerek genel doğruluk oranı hesaplanmıştır. Piksel tabanlı kontrollü sınıflandırma işlemi sonucunda bulunan yanan alanlar ile arazi kullanım haritası birleştirilerek örtüşme analizi yapılmıştır. Böylece arazi türlerinin yangının etkisi üzerindeki etkisi değerlendirilmiştir.

\section{Kullanılan Veriler ve Çalışma Alanı}

Çalı̧̧mada, arazi sınıfları, hava durumu, orman yangını istatistikleri, meteoroloji, yükseklik ve uydu görüntülerini kapsayan veri setleri oluşturulmuştur. Bu çalışma kapsamında kullanılan verilerin, yılları, özellikleri ve temin edilen yerlerin bilgisi Tablo 1'de gösterilmiştir. 
Tablo 1: Kullanılan veriler

\begin{tabular}{|c|c|c|c|}
\hline \multicolumn{2}{|c|}{ Uydu } & Arazi Kullanımları & Orman Yangınları İstatistikleri \\
\hline United States Geological Survey (USGS) & Copernicus Land Cover & Orman Genel Müdürlüğ̈ \\
\hline *Landsat-8 & $23.08 .2016-29.06 .2019$ & *CORINE 2018 & *Deliömerli Yangını Hasar Tespit Sonuçları \\
& $30.06 .2017-09.07 .2017$ & & \\
\hline
\end{tabular}

Uydu görüntüsü Şekil 2'de verilmiş olan çalışma alanı, İzmir'in Menderes İlçesi'ne bağlı Deliömerli Mahallesi'nde bulunan $27^{\circ} 01^{\prime} 30^{\prime \prime} \mathrm{D}$ ile $27^{\circ} 05^{\prime} 00^{\prime} \mathrm{D}$ boylamları ve $38^{\circ} 06^{\prime} 00^{\prime \prime} \mathrm{K}$ ile $38^{\circ} 10^{\prime} 00^{\prime \prime} \mathrm{K}$ enlemleri arasında kalan bölgedir. Bu bölge Akdeniz İklimi etkisi altındadır. Bu sebeple yılın beş ayı (Mayıs, Haziran, Temmuz, Ağustos, Eylül) bölgede sıcaklıklar $20^{\circ} \mathrm{C}$ civarında seyretmektedir. Bölgenin bitki örtüsü büyük çoğunlukla iğne yapraklı ormanlar, karışık ormanlar ve tarım arazilerinden oluşmaktadır. Yerleşimin yoğun olmamasından dolayı ormanlar açısından zengindir.

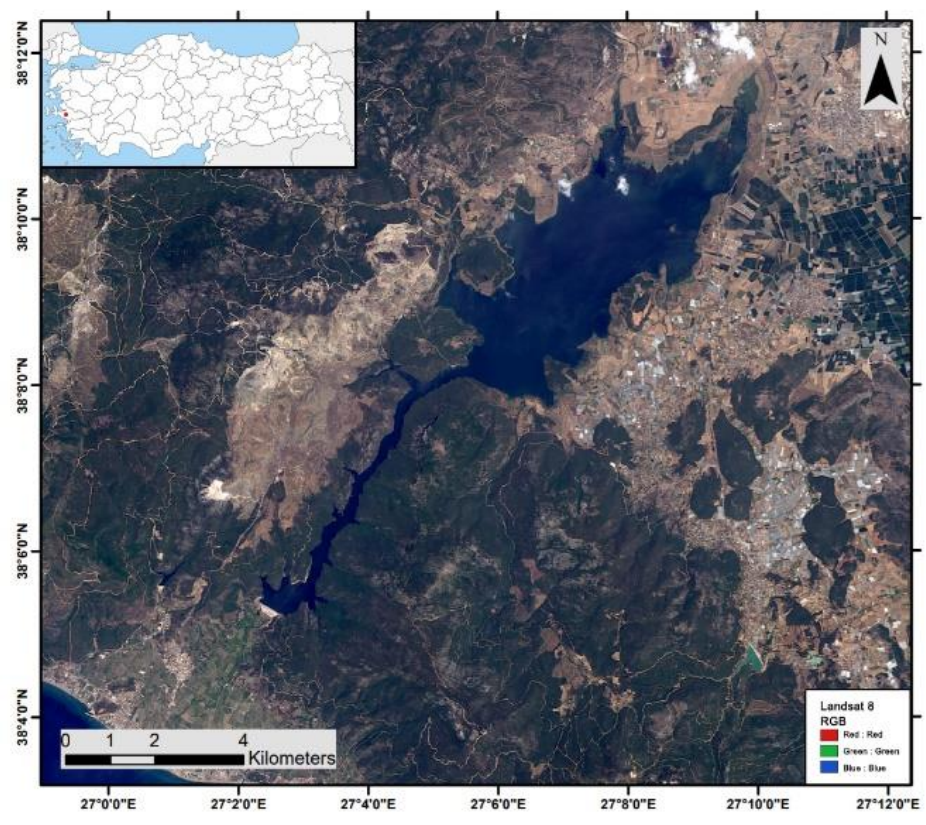

Şekil 2: Çalışma alanına ait uydu görüntüsü (Landsat-8)

\section{Uygulamalar}

Yangın bölgesi üzerinde yapılan Yer Yüzey Sıcaklığı (YYS) analizi, Normalize Edilmiş Bitki Örtüsü İndeksi (NDVI), Normalize Edilmiş Yanma Şiddeti (NBR), piksel tabanlı kontrollü sınıflandırma ve yangından etkilenen arazi kullanım sınıflarının tespiti çalışmaları bu bölümde anlatılmıştır.

\subsection{Yer Yüzey Sıcaklığı Analizi}

Uydu görüntüleri kullanılarak bir yüzeyin sıcaklık değişimi analiz edilebilmekte ve yanmış alan tespit edilebilmektedir. Bu uygulamada yangının toprak üzerinde yarattığı etkiyi görmek amacıyla Landsat-8'in termal bantlarından biri olan 10 numaralı bant kullanılarak yangın öncesi ve sonrasına ait yanan bölgenin yüzey sıcaklıkları tespit edilmiştir. Yangın öncesi için 30 Haziran 2017, yangın sonrası için ise 9 Temmuz 2017 tarihli uydu görüntüleri kullanılmıştır.

İlk olarak (1) numaralı denklem kullanılarak termal bandın piksel değerleri, spektral radyans $\left(\mathrm{L}_{\lambda}\right)$ değerlerine dönüştürülmüştür. Radyans ifadesi, belirli bir dalga boyunda, belirli bir açı yaparak alandan yansıyan enerjinin miktarı olarak tanımlanmaktadır (Yıldız vd. 2017). Sıcaklık da bir enerji olduğundan sıcaklık değerlerinin hesaplanabilmesi için enerji birimine geçmek gerekmektedir. Spektral randyans değerleri hesaplandıktan sonra, (2) numaralı denklem kullanılarak parlaklık sıcaklığı değerlerine geçilmiştir. Parlaklık sıcaklığı (T), dünya atmosferinin en yüksekte bulunan noktasından yukarıya doğru ilerleyen mikrodalga yayılımının parlaklık değerleridir. Parlaklık sıcaklığının belirlenmesinden sonra (3) numaralı denklem kullanılarak bitki örtüsü oranı $\left(\mathrm{P}_{\mathrm{v}}\right)$ hesaplanmıştır. Bu değerin hesaplanmasında (6) numaralı denklem kullanılarak elde edilen maksimum ve minimum NDVI değerleri kullanılmıştır. Bitki örtüsü oranı kullanılarak (4) numaralı denklem yardımıyla yayınırlık değeri (LSE) hesaplanmıştır. Yayınırlık değeri, yer yüzeyi sıcaklıklarının hesaplanmasında kullanılan bir parametredir. Yayınırlık değerinin elde edilmesinin birçok yöntemi vardır. NDVI aracılığılla hesaplama da bunlardan biridir. 


$$
\begin{aligned}
& \mathrm{L}_{\lambda}=\mathrm{M}_{\mathrm{L}} * \mathrm{Q}_{\mathrm{cal}}+\mathrm{A}_{\mathrm{L}}-\mathrm{Q}_{\mathrm{i}} \\
& \mathrm{T}=\frac{\mathrm{K} 2}{\mathrm{In}\left(\frac{\mathrm{K} 1}{\mathrm{~L} \lambda}+1\right)}-273,15 \\
& \mathrm{P}_{\mathrm{v}}=\left(\frac{\mathrm{NDVI}-\mathrm{NDVI}_{\min }}{\mathrm{NDVI}_{\text {maks }}-\mathrm{NDVI}_{\min }}\right)^{2} \\
& \mathrm{LSE}=0,004 * \mathrm{P}_{\mathrm{V}}+0,986
\end{aligned}
$$

Son olarak parlaklık sıcaklığı ve yayınırlık değeri kullanılarak yer yüzey sıcaklığının (LST) belirlenmesi gerekmektedir. (5) numaralı denklem kullanılarak yangın bölgesine ait yüzey sıcaklıkları hesaplanmıştır. Bu aşamalar yangın öncesi ve sonrasına ait uydu görüntüleri üzerinde uygulanmıştır. Bulunan sıcaklık değerleri Şekil 3 'te gösterilmiştir. Kentleşmenin ve tarımın olduğu bölgelerde sıcaklığın yüksek olmasının sebebi, beton, asfalt, kaldırım gibi insan eliyle yapılmış doğal olmayan malzemelerin güneşten gelen ısıyı yeşil alanlara kıyasla daha fazla emmesidir. Sıcaklığın bu şekilde tutulması kentlerin çevresine göre daha sıcak olmasına neden olmaktadır. Bu duruma "Kentsel Isı Adası" adı verilmektedir (Mercan 2020).

$$
\mathrm{LST}=\frac{\mathrm{T}}{1+\left(\lambda * \frac{\mathrm{T}}{\mathrm{h} * \mathrm{c} / \mathrm{s}}\right) * \operatorname{In}(\mathrm{LSE})}
$$
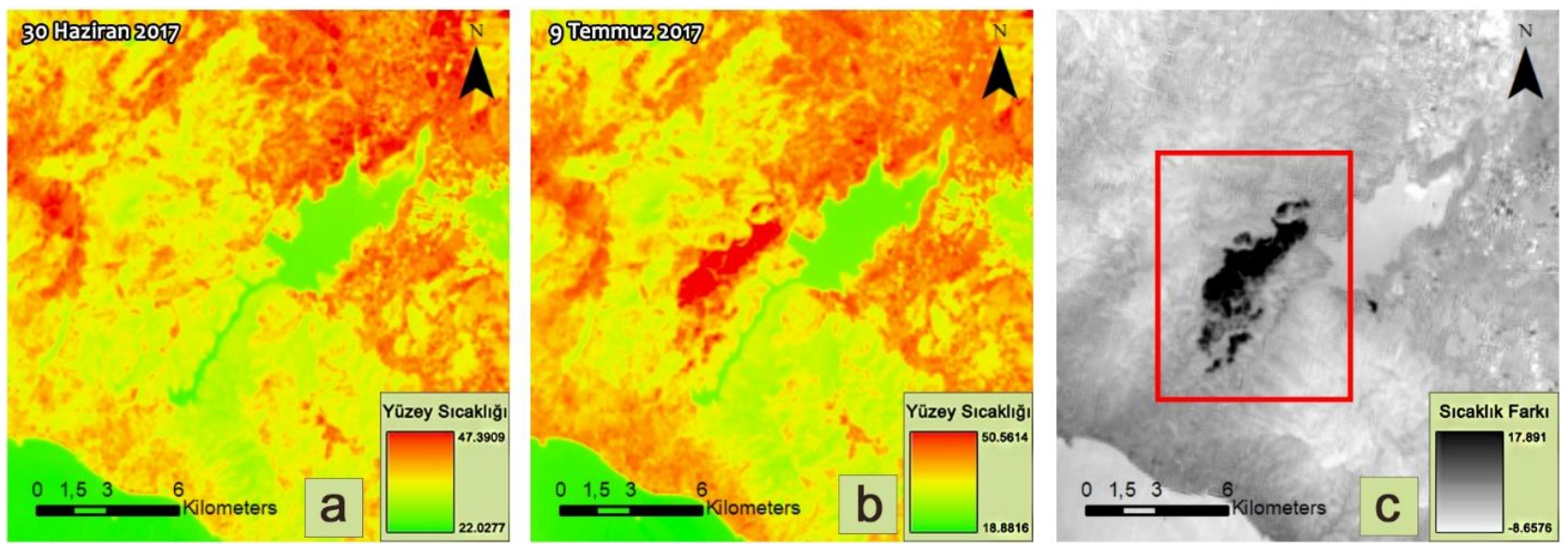

Şekil 3: Yer yüzey sıcakı̆ğı analizi a)yangın öncesi b)yangın sonrası c)fark

Yangın sonrası yüzey sıcaklığı haritası incelendiğinde, yangın bölgesinin sıcaklığının çevresinden bağımsız olarak yükselmiş olduğu görülmektedir. Yangın bölgesinin sıcaklık değerleri $45-50^{\circ} \mathrm{C}$ arasında değişmektedir. Yangının söndürülmesinin üzerinden 5 gün geçmesine rağmen toprak hâlâ yüksek sıcaklıktadır. Sıcaklık değişimini tespit etmek amacıyla yangın öncesi ve sonrası görüntülerin farkı alındığında yangın bölgesinin sıcaklığındaki normal olmayan değişim görülebilmektedir. Fark analizine göre yangın bölgesinin sıcaklığı yangın sonrasında $18^{\circ} \mathrm{C}$ 'ye kadar yangın öncesi değerlerinden farklılık göstermektedir. Yanan bölgenin sıcaklık değişimini diğer arazi kullanım sınıflarıyla karşılaştırmak amacıyla, Arcmap üzerinden oluşturulan yangın öncesi ve sonrasına ait raster görüntüleri (Şekil 3) ve arazi kullanım haritası üzerine toplam 1.300 nokta rastgele olarak atılmıştır. Atılan noktaların konumları Şekil 4'te gösterilmiştir. Bu karşılaştırmanın amacı yangının meydana getirdiği sıcaklık değişiminin tespit edilmesidir. Rastgele olarak atılan 1.300 nokta ilk olarak Copernicus CORINE Land Cover üzerinden ücretsiz olarak elde edilen CORINE arazi kullanım haritasıyla "spatial join” işlevi kullanılarak bağlanmıştır. Böylece her bir noktanın hangi arazi kullanım sınıfının üzerinde bulunduğu tespit edilmiştir. Yapılan karşılaştırma işlemlerinde kullanılmak amacıyla bölgede bulunan 13 CORINE arazi kullanım sınıfı seçilmiştir. 


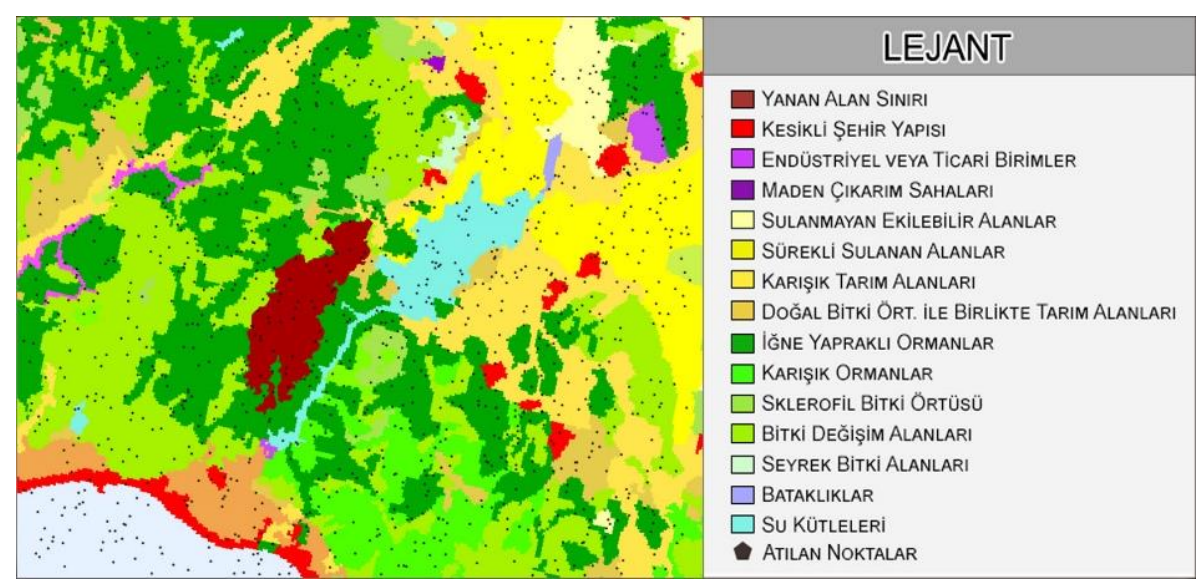

Şekil 4: Sıcaklık değişimini tespit etmek amacıyla atılan noktaların konumları ve CORINE arazi kullanım sınıfları

Atılan noktalar yangın öncesi ve sonrası için yapılmış olan yer yüzey sıcaklık analizi sonuçları ile mekânsal birleştirme fonksiyonu kullanılarak birleştirilmiştir. Böylece her bir noktanın arazi kullanım sınıfının yanında yangın öncesi sıcaklık değeri ve yangın sonrası sıcaklık değerine de sahip olması sağlanmıştır. Bölgede bulunan kentsel alan kategorisinin tek üyesi olan "Kesikli Şehir Yapısı” arazi kullanım sınıfının sıcaklık karşılaştırması Şekil 5'te verilmiştir.

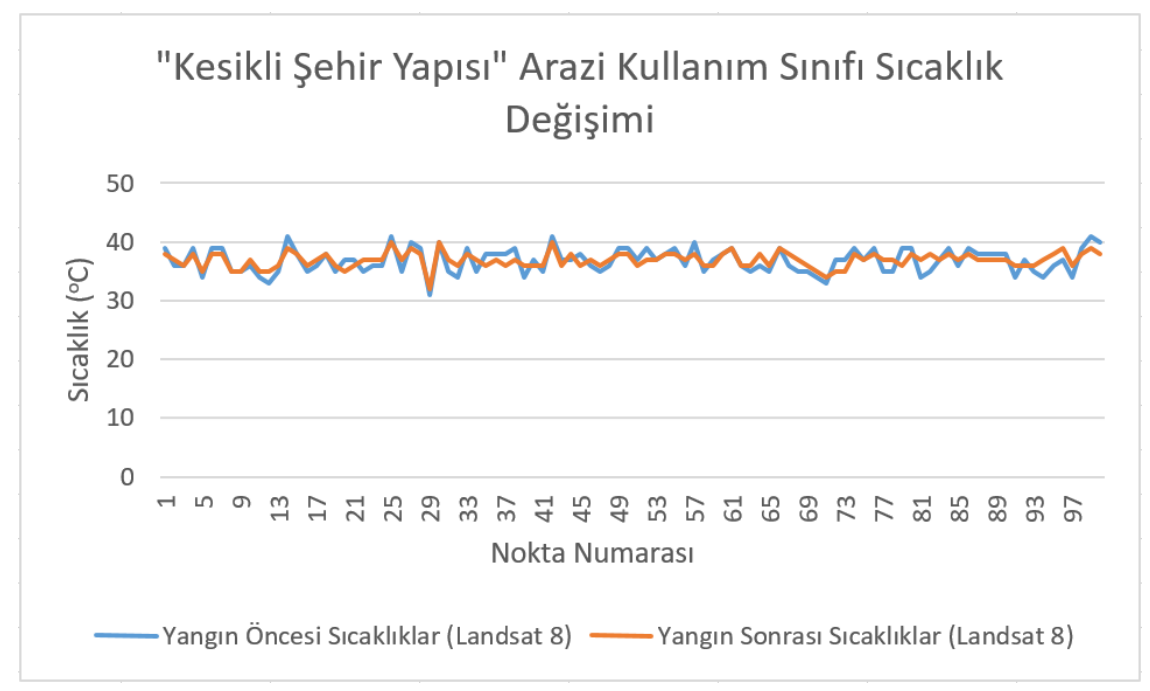

Şekil 5: "Kesikli Şehir Yapısı" CORINE arazi kullanım sınıfı sıcaklık değişimi (Landsat-8)

"Kesikli Şehir Yapısı" arazi kullanım sınıfında yangın öncesi ve yangın sonrası yüzey 1sısında ani bir değişiklik yaşanmamıştır. Kentsel ısı adası kavramının da açıkladığı gibi şehir sıcaklıklarının beton, asfalt, kaldırım vb. tarafından tutulmasından dolayı şehir bölgesinin sıcaklığı yüksek sıcaklıklara sahiptir. Yüzey 1 sısı $32^{\circ} \mathrm{C}$ ile $41^{\circ} \mathrm{C}$ arasında değişmektedir. Maksimum sıcaklık farkı $3^{\circ} \mathrm{C}$ 'dir. Yangın öncesi ve sonrası korelasyon oranı 0.74 olarak hesaplanmıştır. Korelasyon oranı iki değişken arasındaki doğrusal ilişkinin ölçüsüdür. Bu oran incelenen değişkenlerin birimlerinden bağımsızdır ve -1 ile 1 arasında bir değer almaktadır. Korelasyon katsayısının 0'a yaklaşması değişkenler arasındaki ilişkinin zayıf olduğunu göstermektedir. Değişkenler birlikte artıyor veya azalıyorsa pozitif yönde, değişkenlerden biri artarken diğeri azalıyorsa ise negatif yönde bir ilişki vardır.

Bölgede bulunan tarım alanları kategorisine dâhil olan "Sulanmayan Ekilebilir Alanlar", "Sürekli Sulanan Alanlar", "Meyve Bahçeleri”, "Karışık Tarım Alanları" ve "Doğal Bitki Örtüsü ile Birlikte Bulunan Tarım Alanları” sınıflarının sıcaklık değişimlerini gösteren grafikler Şekil 6’de gösterilmiştir. Bu grafikler incelendiğinde yangın öncesi ve sonrası sıcaklık değerlerinde normal olmayan bir değişim yaşanmadığı gözlenmektedir. "Tarım Alanları" arazi kullanım sınıflarına ait yangın öncesi ve sonrası sıcaklık değerlerinde sıra dışı bir değişim yaşanmadığı gözlenmektedir. Yangın öncesi ve sonrasında bütün grafikler değerlendirildiğinde maksimum sıcaklık farkı $6^{\circ} \mathrm{C}$ 'dir. Yangın sonrasında “Tarım Alanları" arazi kullanım sınıflarının yüzey sıcaklıklarında hava sıcaklığının azalmasına bağlı düşüş yaşanmıştır. Ayrıca "Tarım Alanları" arazi kullanım sınıflarının sıcaklıklarının yüksek olmasının sebebi olarak da buradaki yapılaşmalar gösterilebilir. Korelasyon oranları ise sırasıyla, 0.81, 0.97, 0.87, 0.89 ve 0.93'tür. Bütün grafikler için korelasyon oranının 1 değerine yaklaşması yangın öncesi ve yangın sonrası sıcaklıklar arasındaki ilişkinin kuvvetli olduğunu göstermektedir. 

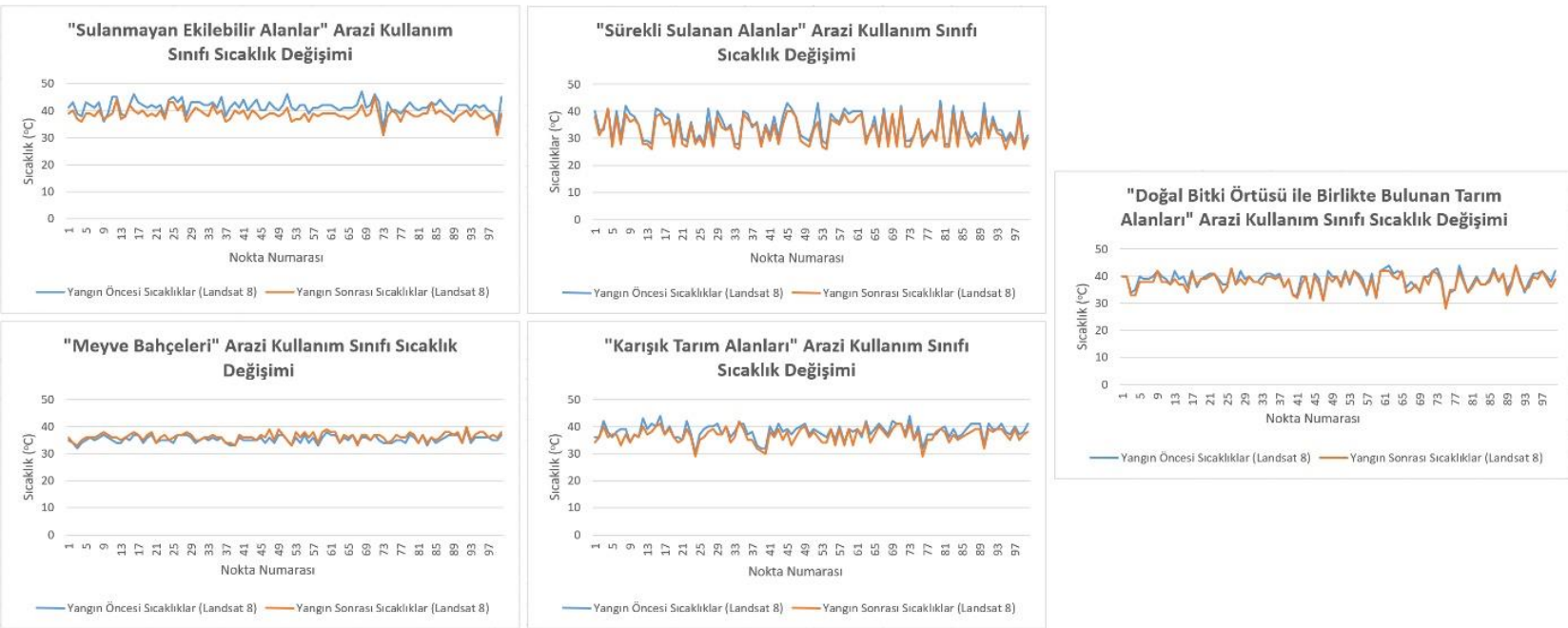

Şekil 6: "Tarım Alanları" kategorisinde bulunan CORINE arazi kullanım sınıflarına ait sıcaklık değişimleri (Landsat-8)

Bölgede bulunan bir diğer kategori olan ormanlar ve doğal alanlar kategorisine dâhil olan "Geniş Yapraklı Ormanlar”, "İğne Yapraklı Ormanlar”, "Karışık Ormanlar”, "Sklerofil Bitki Örtüsü” ve "Bitki Değişim Alanları” sınıflarına ait sıcaklık değişim grafikleri Şekil 7'de gösterilmiştir. Ormanlar ve Doğal Alanlar sınıfına ait grafikler incelendiğinde yangın öncesi ve sonrası arasındaki maksimum sıcaklık farkı $6^{\circ} \mathrm{C}$ 'dir. Tarım Alanları sınıfında olduğu gibi Orman ve Doğal Alanlar sınıfında da hava sıcaklığına bağlı yüzey 1sısında düşüş yaşanmıştır. Bu arazi kullanım sınıfına ait korelasyon oranları ise sırasıyla, $0.85,0.85,0.78,0.96$ ve 0.87 'dir. Bu da bu değerler arasında pozitif bir ilişki olduğunu göstermektedir.
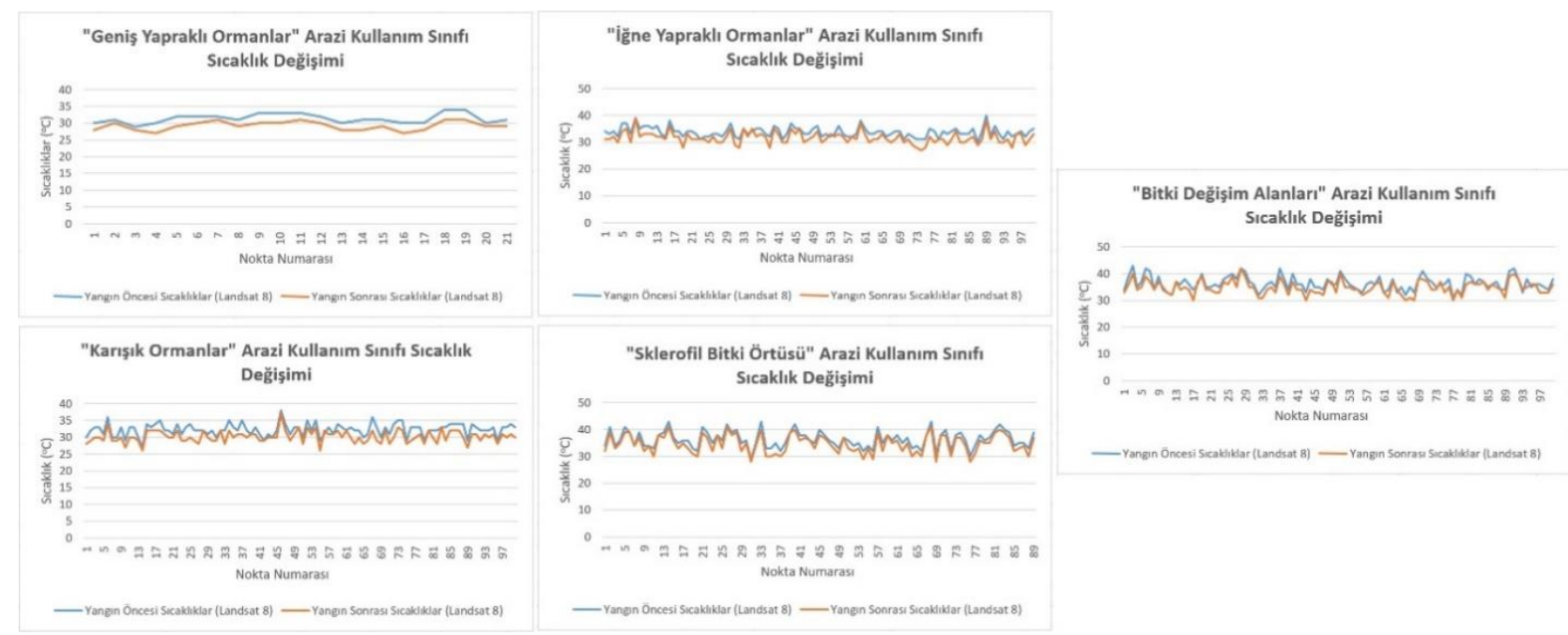
Şekil 7: "Ormanlar ve Doğal Alanlar” kategorisinde bulunan CORINE arazi kullanım sınıflarına ait sıcaklık değişimleri
(Landsat-8)

Bölgede bulunan ve sıcaklıkları karşılaştırılan son kategori olan sulak alanlar kategorisinde bulunan "Su Kütleleri” ve "Deniz ve Okyanus" arazi kullanım sınıflarına ait sıcaklık karşılaştırması Şekil 8'de verilmiştir. Şekil 8'deki grafikler incelendiğinde hem baraj hem de deniz suyu sıcaklıklarında yangın öncesi değerlerinin daha yüksek olduğu görülmektedir. Bu farkın hava sıcaklıklarından kaynaklanmış olması muhtemeldir. Su Kütleleri Arazi kullanım sınıfında maksimum sıcaklık fark $16^{\circ} \mathrm{C}$, korelasyon oran 10.56 'dır. Deniz ve Okyanus arazi kullanım sınıfına ait maksimum sıcaklık fark $14^{\circ} \mathrm{C}$, korelasyon oranı ise $0.18^{\prime}$ 'dir.

Yangın öncesi hava sıcaklıklarının yüksek olması yaşanan yangın için de hazırlayıcı bir etken olmuştur. Yapılan bütün karşılaştırmalarda çok küçük farklarla da olsa yangın bölgesi dışındaki sınıfların tamamında yangın öncesi sıcaklık değerleri, yangın sonrası sıcaklık değerlerinden daha yüksektir. Yangın bölgesi dışındaki arazi kullanım sınıflarının yüzey sıcaklıkları yaşanan hava koşullarına bağlı olarak değişim göstermektedir. 


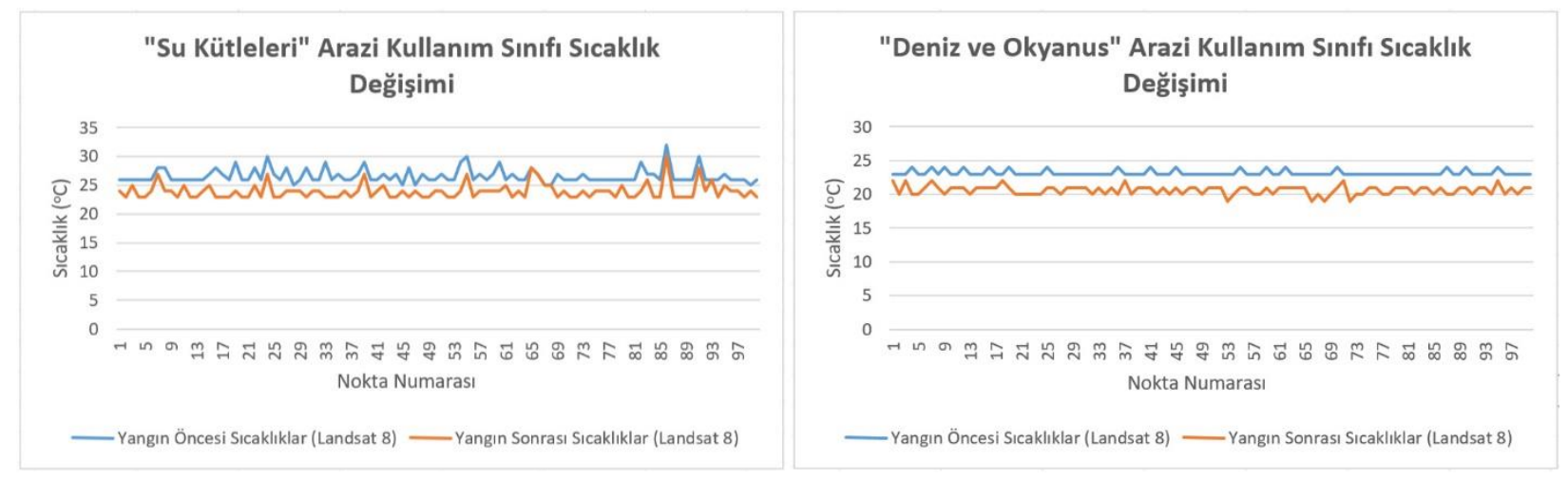

Şekil 8: "Sulak Alanlar" kategorisinde bulunan CORINE arazi kullanım sınıflarına ait sıcaklık değişimleri (Landsat-8)

Çalışmanın temelini oluşturan yangın bölgesine atılan 100 noktanın yangın öncesi ve sonrası sıcaklıkları karşılaştırılarak elde edilen karşılaştırma grafiği Şekil 9'da verilmiştir.

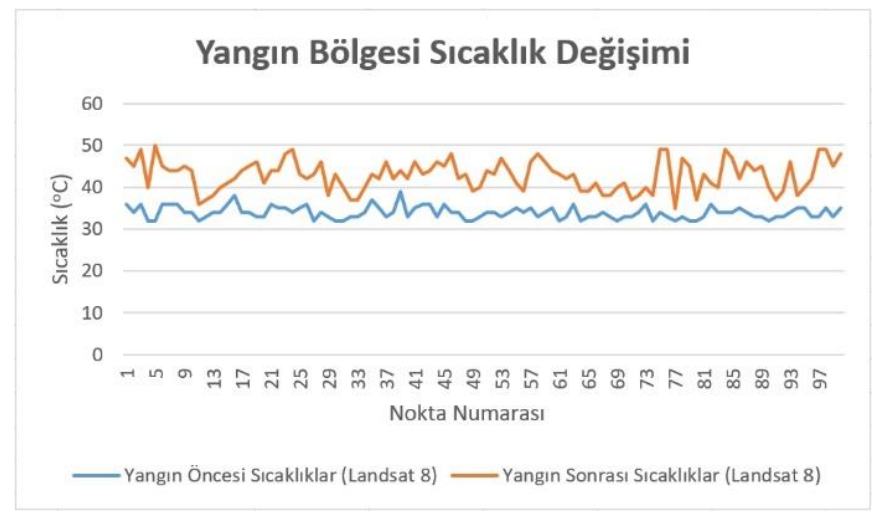

Şekil 9: Yangın bölgesine ait sıcaklık değişimi (Landsat-8)

Yapılan çalışma sonucunda yangının sebep olduğu ısınma açık bir şekilde görülmektedir. Atılan noktaların ortalamaları alınarak bulunan, bölgenin yangın öncesi ortalama sıcaklık değeri $34^{\circ} \mathrm{C}$, yangın sonrası ortalama sıcaklık değeri ise $43^{\circ} \mathrm{C}$ olarak hesaplanmıştır. Ortalamalar arasındaki fark $9^{\circ} \mathrm{C}$ olmasına rağmen noktalar özelinde incelendiğinde bazı yerlerde bu fark $18^{\circ} \mathrm{C}^{\prime}$ ye kadar çıkmaktadır. Yangın bölgesine ait korelasyon değeri ise $0.25^{\prime}$ tir. Korelasyon değerinin 0'a yakın çıkmış olması yangın öncesi ve sonrası değerlerin arasındaki ilişkinin zayıf olduğunu göstermektedir. Bu da yangın bölgesinin ani isınmasının sonucudur.

\subsection{Yanan Alan Tespiti Analizleri}

Bu başlık altında yanan bölgenin tespiti için Normalize Edilmiş Bitki Örtüsü İndeksi (NDVI), Normalize Edilmiş Yanma Şiddeti (NBR) ve piksel tabanlı kontrollü sınıflandırma analizleri gerçekleştirilmiştir.

\subsubsection{Normalize Edilmiş Bitki Örtüsü İndeksi (NDVI)}

Uzaktan algılama uygulamalarında yeşil bitki örtüsünün tespitinde ve zaman içindeki değişiminin izlenmesinde en sık kullanılan indeks NDVI indeksidir. Bu indeks ile yakın kızılötesi ve kırmızı bant görüntüleri matematiksel bir oran şeklinde ifade edilir. -1 ile 1 değerleri arasında değiş̧en bir aralıkta tanımlanmaktadır. Canlı bitki örtüsünün bulunduğu bölümlerde bu değer +1 'e kadar çıkarken, bitki örtüsü seyrekleştikçe ve sağllğı düştükçe 0'a yaklaşmaktadır. Bitki örtüsünün bulunmadığı alanlarda ise -1 değeri almaktadır. Bitkilerin canlılık durumunu belirten bu indeks, yanmış bölgelerin tespiti için kullanıma uygundur.

NDVI $=\frac{\text { NIR }- \text { KIrmızı Bant }}{\text { NIR + Kırmız Bant }}$

Landsat-8 uydu görüntüsü üzerine, yangın öncesi ve sonrası için NDVI uygulandığında yanmış alan siyah olarak gözükmektedir. Yangın öncesi +1 değerine yaklaşan ve beyaza yakın gri tonları şeklinde görünürken yangın bölgesi, yangın sonrası ise -1 değerine yaklaşarak siyah renkte görünmektedir. Şekil 10'da görülen değişim saptama analizi sonucunda tahrip olan yeşil alan 13.740 piksel olarak hesaplanmıştır. 
Bu sonucun alansal karşllığ 1.235 hektara karşıllık gelmektedir. Orman Genel Müdürlüğü (OGM) tarafindan yapılan hasar tespiti sonucunda toplam 1.200 hektar alanın yanarak hasar gördüğü tespit edilmiştir. OGM hasar tespit sonuçları ve NDVI değişim saptama sonuçları tutarlıdır.
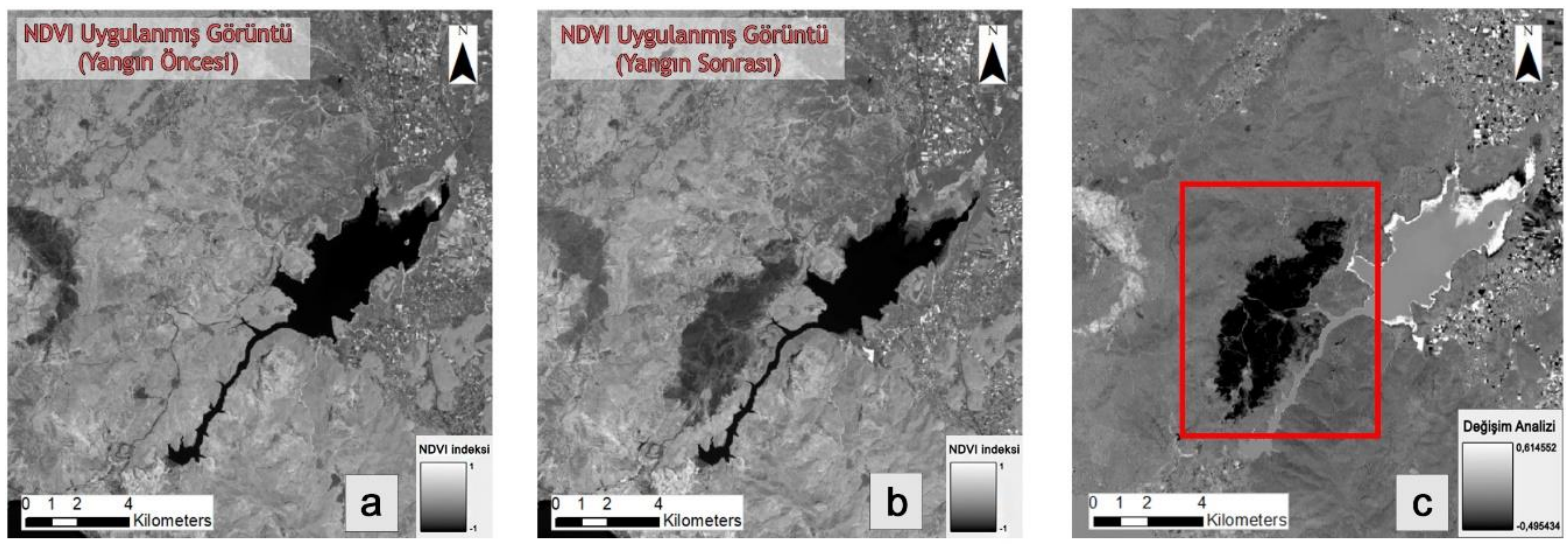

Şekil 10: NDVI uygulaması a)yangın öncesi b)yangın sonrası c)fark

\subsubsection{Normalize Edilmiş Yanma Şiddeti (NBR)}

Bitki örtüsünün fiziksel özellikleri yerine kimyasal değişimlerinin incelenmesidir. Orman alanlarında yangın öncesi ve yangın sonrası değişikliği tespit amacıyla kullanılan bu indeks, yakın kızılötesi ve kısa dalga kızılötesi bantlarının matematiksel oranı ile ifade edilmektedir (7). NBR, canlı bitki örtüsü, nem içeriği ve yangından sonra meydana gelebilecek değişimlere özellikle duyarlıdır. Yangın öncesi ve sonrasına ait Landsat-8 uydu görüntüleri üzerine uygulanan NBR indeksi sonuçları Şekil 11'de görülmektedir. NBR uygulaması sonucunda yangından etkilenen bölgeler siyah olarak gözükmektedir. Siyah renk koyulaşması yanma şiddetinin artışı anlamına gelmektedir. NBR uygulanmış yangın sonrası uydu görüntüsü incelendiğinde yanmış alanlar siyah olarak gözükmektedir. NBR farkı alınarak yangın öncesi ve sonrası görüntüler için değişim analizi yapıldığında ise yanmış bölge ve yangın şiddeti görülebilmektedir. NBR farkı piksel bazında incelendiğinde kimyasal olarak etkilenmiş bölgenin karşıllı̆ı 1.221 hektar alan olarak hesaplanmıştır. Hesaplanan bu NBR değeri de OGM hasar tespit sonuçları ile tutarlıdır.

$\mathrm{NBR}=\frac{\mathrm{NIR}-\mathrm{SWIR}}{\mathrm{NIR}+\text { SWIR }}$
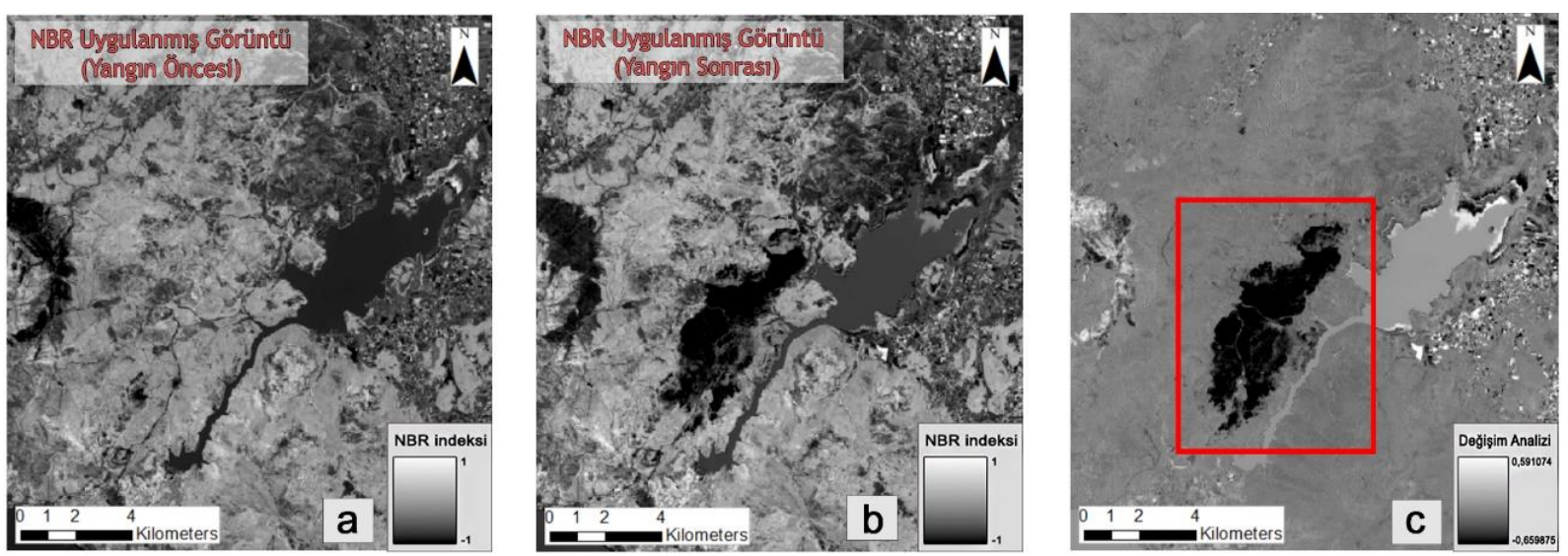

Şekil 11: NBR uygulaması a)yangın öncesi b)yangın sonrası c)fark

\subsubsection{Piksel Tabanlı Kontrollü Sınıflandırma}

NBR ve NDVI indekslerinin dışında yanmış bir alanın tespiti amacıyla kullanılabilecek bir diğer yöntem de literatürde sıklıkla kullanılan piksel tabanlı kontrollü sınıflandırma yöntemidir (Dereli 2019). Maksimum olabilirlik yöntemi, yapılan tüm gözlemlerin arasından en muhtemel olan sonucun seçildiği bir kestirim yöntemidir. Bu yöntemde amaç, gözlenen değeler ile tahmin edilen değişkenin değerleri arasındaki olabilirliğin maksimum yapılmasıdır (Özdemir vd. 2011). Her bir pikselin tek bir arazi örtüsü sınıfına ataması yapılacak şekilde sınıflandırılması amaçlanmaktadır. Çalışma alanındaki arazi örtüsünün genel olarak belirlenmesi amacıyla arazi örtüsünü temsil eden 6 sınıf seçilmiştir. 
Maksimum olabilirlik yöntemi kullanılarak yangın öncesi ve sonrası için uygulanan kontrollü sınıflandırma işlemi ve sınıfları Şekil 12'de, işlemin sonuçları ise Tablo 2'de görülmektedir.
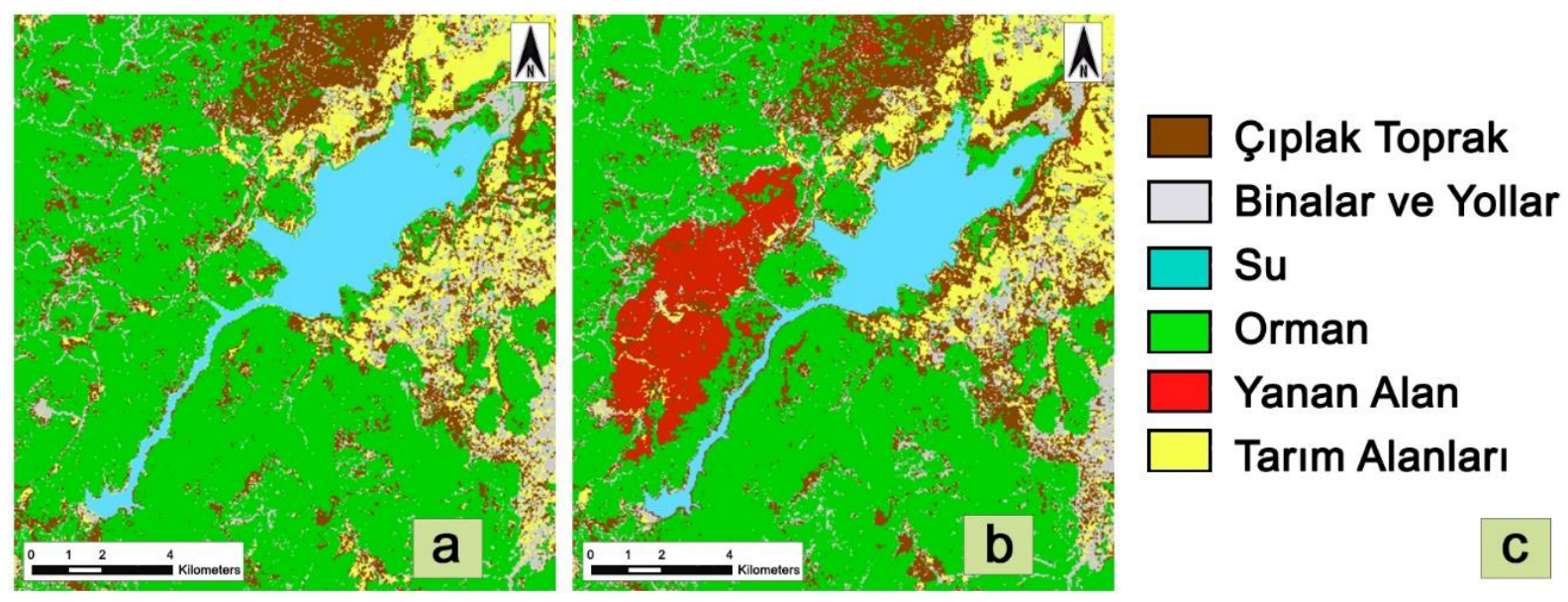

Şekil 12: Piksel tabanlı kontrollü sınıflandırma a)yangın öncesi b)yangın sonrası c)sınıflar

Tablo 2: Sınıflandırma işlemi sonunda bulunan alanlar

\begin{tabular}{|c|c|}
\hline Sinıflar & Alan [ha] \\
\hline Çıplak Toprak & 4143,29 \\
\hline Binalar ve Yollar & 2657,52 \\
\hline Su & 1336,65 \\
\hline Orman & 11804,93 \\
\hline Yanan Alan & 1296,34 \\
\hline Tarım Alanları & 2509,08 \\
\hline
\end{tabular}

Arazi üzerinden 6 kategori için örnek seçme işleminden sonra maksimum olabilirlik yöntemi kullanılarak sınıflandırma işlemi gerçekleştirilmiştir. Sınıflandırma işlemi tamamlandıktan sonra yanmış alan miktarının tespit edilebilmesi amacıyla raster veri vektör veriye dönüştürülerek alan hesabı yapılmıştır. Yapılan kontrollü sınıflandırma işlemi sonucunda yanmış alan 1.296 hektar alan tespit edilmiştir. Bu değer Orman Genel Müdürlüğü (OGM) tarafından yapılan hasar tespiti sonucunda açıklanan değerlerden çok az bir miktar fazladır. Kontrollü sınıflandırma işlemi yapılırken seçilen sınıfların birbirine yakın piksel tonlarına sahip olması durumunda hatalı sonuçlar vermesi olasıdır. Yanmış alan ve çıplak toprak sınıfları kontrollü sınıflandırma açısından birbirinden ayırt edilmesi zor sınıflardır. Piksel tabanlı kontrollü sınıflandırma işleminin kontrolünü sağlamak ve genel doğruluk oranını hesaplamak amacıyla doğruluk analizi yapılmıştır. Yer gerçeği olarak literatürde sıklıkla seçilen sınıflandırılan görüntü yerine, görüntünün alındığı tarihe en yakın Ekim 2017 tarihli Google Earth uydu görüntüsü kullanılmıştır. Görüntü üzerinde sınıfları en iyi temsil eden noktalar seçilmiştir. Örnek olarak, görüntü üzerinden orman ve toprak sınırı gibi belirsiz noktalar değil, tam olarak ormanı ifade eden alandan bir nokta yer gerçeği olarak seçilmiştir. Google Earth uydu görüntüsü üzerine 446 adet referans noktası atılmıştır. Bu noktalar piksel tabanlı kontrollü sınıflandırma işlemi yaparken oluşturulan sınıflara göre isimlendirilerek Google Earth üzerinde işaretlenmiş ve veri tabanına yer gerçeği bilgileri atanmıştır. Her sınıfı temsil eden yaklaşık 100 ile 50 nokta arasındaki noktada değerlendirme yapılmıştır. Yer gerçeği veri tabanı ArcMap'e aktarılarak kontrollü sınıflandırma işlemi ile örtüştürülmüştür. Yer gerçeği noktaları ve sınıflandırma noktaları hata matrisi oluşturularak tüm doğruluk ve kappa istatistikleri ile değerlendirilmiştir. (Tablo 3). Bu hata matrisi kullanılarak gerçekleştirilen doğruluk analizi sonucunda genel doğruluk oranı \%94.6 olarak hesaplanmıştır. Kontrollü sınıflandırma işleminin doğruluğunu tespit etmek amacıyla uygulanabilecek bir diğer yöntem kappa indeksidir. Kappa değeri karşılaştırılan iki görüntü arasındaki ilişkiyi belirtmektedir. Kappa değeri 0,92 olarak bulunmuştur. Bu değerin 1'e oldukça yakın olduğu görülmektedir. Bu değerin 1'e yakın çıkması, iki görüntü arasındaki farkın minimum düzeyde olduğunu göstermektedir. Tüm doğruluk ve kappa istatistiği değerlerinin yeterli sonuç vermesi sebebiyle nokta sayısı yeterli görülmüştür. Ayrıca yine bu hata matrisi kullanılarak kullanıcı doğruluğu ve üretici doğruluğu değerleri hesaplanmıştır. Bu değerler incelendiğinde en belirgin hataların, çıplak toprak sınıfındaki kullanıcı kaynaklı hatalar olduğu tespit edilmişstir. Bunun sebebi olarak da, veri grubunun toplandığı uydu görüntüsü ile doğruluk analizinin yapıldığı Google Earth uydu görüntüsü arasındaki zamansal farklılıklar gösterilebilir. Orman sınıfında bulunan alanların zaman içerisindeki değişimleri çıplak toprak sınıfında tespit edilmesine sebep olmuştur. 
Tablo 3: Sınıflandırma işlemine ait hata matrisi

\begin{tabular}{lccccccccc}
\hline & Su & $\begin{array}{c}\text { Yanan } \\
\text { Alan }\end{array}$ & Orman & $\begin{array}{c}\text { Tarım } \\
\text { Alanı }\end{array}$ & $\begin{array}{c}\text { Bina } \\
\text { ve } \\
\text { Yollar }\end{array}$ & $\begin{array}{c}\text { Çıplak } \\
\text { Toprak }\end{array}$ & $\begin{array}{c}\text { Satır } \\
\text { Toplamı }\end{array}$ & $\begin{array}{c}\text { Kullanıcı } \\
\text { Doğruluğu }\end{array}$ & $\begin{array}{c}\text { Üretici } \\
\text { Doğruluğu }\end{array}$ \\
\hline Su & 23 & 0 & 0 & 0 & 0 & 0 & 23 & $100 \%$ & $100 \%$ \\
Yanan Alan & 0 & 149 & 1 & 0 & 0 & 0 & 150 & $99 \%$ & $98 \%$ \\
Orman & 0 & 1 & 174 & 1 & 0 & 0 & 176 & $99 \%$ & $96 \%$ \\
Tarım Alanı & 0 & 2 & 0 & 25 & 2 & 3 & 32 & $78 \%$ & $83 \%$ \\
Bina ve Yollar & 0 & 0 & 0 & 2 & 40 & 0 & 42 & $95 \%$ & $89 \%$ \\
Çıplak Toprak & 0 & 0 & 7 & 2 & 3 & 11 & 23 & $48 \%$ & $79 \%$ \\
Sütun Toplamı & 23 & 152 & 182 & 30 & 45 & 14 & 446 & & \\
Tüm Doğruluk : \%94,6 & & & & & & & & \\
Kappa & $\mathbf{0 , 9 2}$ & & & & & & & & \\
\hline
\end{tabular}

\subsubsection{Yangından Etkilenen Arazi Kullanım Sınıflarının Tespiti}

Yangından etkilenen arazi kullanım sınıflarının tespitini yapmak ve bu arazi kullanım sınıflarının yangına etkisini araştırmak amacıyla Şekil 13'de görülen arazi kullanım haritası Copernicus Land Monitoring Service (land.copernicus.eu) üzerinden ücretsiz olarak indirilmiştir. Daha sonra raster formattaki bu arazi kullanım haritası Arcmap üzerinde vektör formata çevrilmiştir. Yapılmış olan piksel tabanlı kontrollü sınıflandırmanın yanan alan katmanı esas alınarak yangın bölgesinin sınırları vektörel olarak elde edilmiş ve Copernicus arazi kullanım sınıfları ile örtüştürülmüştür.

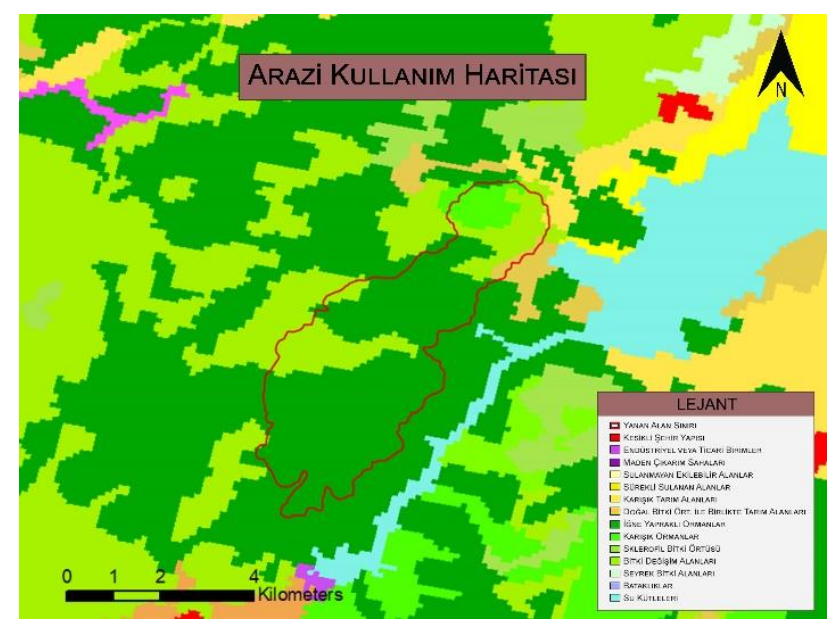

Şekil 13: Yangın bölgesine ait arazi kullanım haritası (CORINE 2018)

Bölgede büyük oranda iğne yapraklı ağaçlar bulunmaktadır. Bu ağaçlar normal ağaçlara göre yangınlardan daha fazla zarar görmektedir. Çünkü iğne yapraklı türler odunu ve yapraklarında reçine bulunması sebebiyle kolayca tutuşmaktadır. Bölgede bol miktarda iğne yapraklı orman bulunması yangının gittikçe büyümesine sebep olmuştur. Yangının ilerleme güzergâhı incelendiğinde yangının iğne yapraklı ormanlar üzerinden kolayca ilerlediği ve yayıldığı görülmektedir. Bunun yanında yangının batı yönünde fazla ilerlememesinin sebebi bölgenin batısının kayalık bir araziye sahip olmasıdır. Bölge bitki değişim alanları açısından zengindir. Bitki değişim alanları çalılık, otsu bitkilerin yer yer ağaçlarla beraber dağıldığı alanları ve doğal orman gelişim alanlarını içermektedir. Aynı zamanda yangının gerçekleştiği bölge karışık ormanlar ve sklerofil bitki örtüsü de içermektedir. Yangın bölgesinde ormanların dışında doğal bitki örtüsü içeren tarım alanları ve karışık tarım alanları bulunmaktadır. Bu kadar ormanlık ve tarım alanlarıyla dolu bir bölge olması sebebiyle yangının hızlıca yayılmasına elverişlidir. Bunun üzerine ek olarak arazi koşullarının kötü olması sebebiyle güçleşen müdahale imkânlarından dolayı yangın büyük alanlara yayılmıştır. Sınıflandırma işlemi sonucunda tespit edilen yanmış alanlar ve arazi kullanım haritası Arcmap üzerinde örtüştürülerek, arazi kullanım sınıfının yangından ne kadar etkilendiğine dair alansal hesaplamalar yapılmıştır (Şekil 14). 


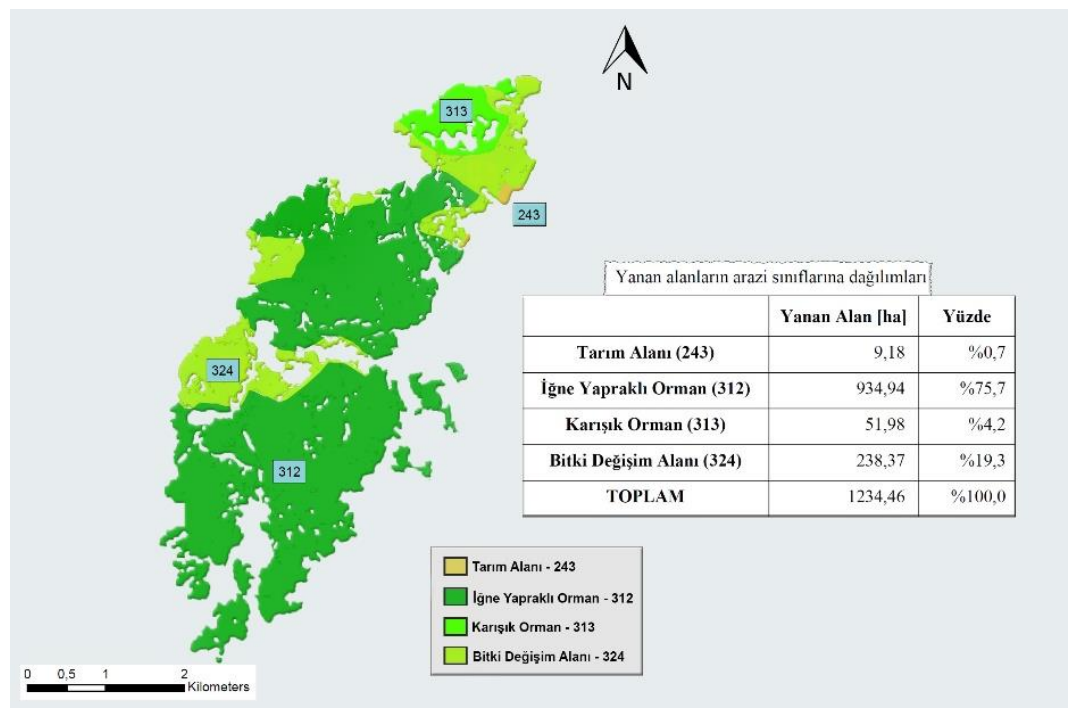

Şekil 14: Kontrollü sınıflandırma işleminin sonuçları ve arazi kullanım haritasıyla birleştirilmesi

Birleştirme işlemi sonrasında yapılan hesaplamalar sonucunda, yanan alanın \%0,7'sinin tarım alanları, \%75,7'sinin Akdeniz kuşağında bol miktarda bulunan ve yapısı gereği yanmaya elverişli olan iğne yapraklı ormanlar, \%4,2’sinin çeşitli ağaçları içeren karışık ormanlar ve \%19,3'ünün arası çalılıklarla kaplı seyrek ağaçların bulunduğu, yeni ormanlaştırılan ya da bozulmuş ağaçlık sahaları temsil eden bitki değişim alanları olduğu tespit edilmiştir. Sınıflandırma sonrası elde edilen yanan alan sınır boyutu ile arazi kullanımı sonucunda elde edilen toplam alan değeri birbiri ile örtüşmemektedir. Temel olarak bunun nedeni sınıflandırma işleminin geniş bir görüntü alanında yapılmasına karşın, yüzdesel olarak yapılan hesaplamanın daha küçük bir alan seçilerek yapılmasıdır. Şekil 12'de görülen yangın bölgesinin dışında da, renk tonlarının benzer olmasından dolayı yanan alan olarak tespit edilen bölgeler bulunmaktadır. Sınıflandırma işleminde yanan alan miktarı, tüm çalışma alanındaki yanan alan bölgelerinin miktarlarının toplamı ile elde edilmiş olması dolayısı ile Şekil 14'te elde edilen yanan alan değeri ile farklılık göstermektedir. Bu nedenden kaynaklı olarak da kontrollü sınıflandırma ile yangından etkilenen arazi kullanım sınıflarının oransal karşılaştırılması sonucu elde edilen toplam alan değerleri farklılık göstermektedir.

\section{Sonuçlar}

Temel olarak orman yangınlarının çıkma nedenleri doğal ve insan kaynaklı olmak üzere ikiye ayrılmaktadır. Orman yangınları insan hayatına büyük zararlar vermektedir. Ağaçlık alanların azalması dünya üzerindeki doğal dengeyi bozmakta, kuraklık ve küresel ısınma gibi hayatımızı derinden etkileyen olaylara neden olmaktadır.

Ülkemizde sıcaklıkların yüksek olduğu Akdeniz ve Ege bölgesinde sık sık orman yangınları yaşanmaktadır. Bu çalışmada 1 Temmuz 2017 tarihinde İzmir'in Menderes ilçesi Deliömerli Mahallesi'nde gerçekleşen, 1.200 hektarlık alanın zarar görmesine neden olan yangın incelenmiştir. $\mathrm{Bu}$ inceleme kapsamında Landsat- 8 uydu görüntüleri kullanılmıştır. İlk olarak yanmış bölgenin tespit edilmesi amacıyla yer yüzey sıcaklığ 1 analizi yapılmıştır. Landsat-8'in termal bandı kullanılarak hesaplanan çeşitli parametreler sonucunda yangın öncesi ve yangın sonrasına ait yer yüzey sıcaklıkları tespit edilmiştir. Yer yüzey sıcaklığı yangın öncesinde $30^{\circ} \mathrm{C}$ civarında iken yangın sonrası $45-50^{\circ} \mathrm{C}$ civarlarına kadar çıktığı görülmüştür. Yangının, bölgenin yüzey sıcaklığı üzerindeki etkisini daha iyi göstermek amacıyla CORINE arazi kullanım haritası ile yer yüzey sıcaklığı analizleri birleştirilmiştir. Sonuçlar doğrultusunda her arazi kullanım sınıfı için yer yüzey sıcaklığının değişimini gösteren grafikler oluşturulmuştur. Grafikler incelendiğinde yanan alan dışındaki arazi kullanım sınıflarının yüzey sıcaklığında normal olmayan bir artışın gerçekleşmediği görülmüştür.

Yanan bölgenin yer yüzey sıcaklı̆̆ Edilmiş Bitki Örtüsü İndeksi (NDVI) ve Normalize Edilmiş Yanma Şiddeti (NBR) indeksleri ve piksel tabanlı kontrollü sınıflandırma işlemi ile yapılmıştır. NDVI indeksi hesaplanarak değişim saptama analizi yapılmış ve sonuçlarına göre yangında zarar gören alanın 1.235 hektar olduğu hesaplanmıştır. Yangın öncesine ve sonrasına ait Landsat-8 uydu görüntülerine NBR indeksi uygulanmıştır. NBR farkı piksel olarak incelendiğinde yangından etkilenen alan 1.221 hektar hesaplanmıştır. Piksel tabanlı kontrollü sınıflandırma işlemi 6 sınıf seçilerek gerçekleştirilmiş, sınıflandırma sonucunda yanan alan 1.296 hektar alan olarak tespit edilmiştir. Yapılan doğruluk analizi sonucunda piksel tabanlı kontrollü sınıflandırma işleminin genel doğruluk oranı \%94,6, kappa istatistiği 0,9238 olarak bulunmuştur. Orman Genel Müdürlüğü tarafından yapılan hasar tespitinde toplam 1.200 hektarlık alanın hasar gördüğü bildirilmiştir. Orman Genel Müdürlüğ̈̈ verileri ile hesaplanan veriler karşılaştırıldığında sonuçların tutarlı olduğu gözlemlenmiştir. 
Bu kapsamda yapılan başka çalışmalar incelendiğinde, Sabuncu ve Özener (2019) tarafından yapılan çalışmada bulunan sonuçlara bakılırsa, Orman Genel Müdürlüğü’nün (OGM) açıkladığı yanan alan verisinin 700 hektar olmasına karşın yapılan analizler sonucunda yanan alan NBR yöntemi ile 695 hektar, NDVI yöntemi ile 711 hektar, piksel tabanlı kontrollü sınıflandırılma ile 665 hektar alan bulunmuştur. Bu verilerin OGM'nin açıkladığı veriler ile tutarlı olduğu belirtilmiştir. Deliömerli yangını için yapılan bu çalışmada, NDVI, NBR ve Piksel tabanlı kontrollü sınıflandırma yöntemleri sonucunda bulunan değerler de OGM'nin açıkladığı değerlerle tutarlıdır. Her iki çalışmada da piksel tabanlı kontrollü sınıflandırma işlemi sonucu, NDVI ve NBR yöntemlerine kıyasla OGM verilerine daha uzak sonuçlar vermiştir. Sabuncu ve Özener (2019) tarafından yapılan çalışmada piksel tabanlı kontrollü sınıflandırma sonucu bulunan yanan alan miktarı OGM'nin açıkladığı hasar tespiti sonucunda bulunan yanan alan miktarından 35 hektar farklıyken, Deliömerli yangını için yapılan bu çalışmada fark 96 hektardır. Bunun sebebi olarak, çalışma alanının daha geniş olmasından dolayı birbirine karışmaya müsait benzer renk tonlarına sahip piksel miktarının artması gösterilebilir.

Deliömerli yangını için yapılan çalışmada kullanılan NDVI, NBR ve kontrollü sınıflandırma yöntemlerinin verdiği sonuçlar karşılaştırıldığında, bütün yöntemler tutarlı sonuçlar verse de NDVI ve NBR sonuçları, kontrollü sınıflandırma sonuçlarına kıyasla, OGM hasar tespit sonucu bildirilen 1.200 hektar alana daha yakındır. Piksel tabanlı kontrollü sınıflandırma yönteminde, diğer iki yönteme kıyasla kullanıcının etkisi daha fazladır. Sınıf sayısı, sınıfların yansıma oranları benzerliği ve seçilen referans sayısı gibi etkenler ortaya çıkan sonucu doğrudan etkilemektedir. Yapılan çalışmada alan tespitindeki farklılığın sebebi de yine bazı sınıfların yansıma değerlerinin birbirine yakın olmasından kaynaklıdır. Çalışma alanı büyüdükçe farklı sınıf sayısı artış göstereceğinden bu hata da büyüyebilmektedir. Çünkü farklı sınıf gurubuna atanması gerekirken küçük alanlar yakın yansıma veren başka bir sınıfa atandığında o sınıfın istatistik değerlendirmesi değişecek ve buda sınıflandırmada hatalara yol açabilecektir. NDVI ve NBR ise, bant oranları dikkate alındığından, bitki örtüsünün fiziksel ve kimyasal değişimleri daha etkin tespit edilmiştir. Yanma olayı bitkinin kimyasal ve fiziksel değişimlere uğramasına sebep olduğundan, bu değişimler üzerinden yapılan analizlerin daha tutarlı sonuçlar verdiği düşünülmektedir.

Vlassova vd. (2014) tarafından yapılan çalışmada Las Hurdes yangını bölgesinde yer yüzey sıcaklığındaki ortalama $\operatorname{artış~} 13^{\circ} \mathrm{C}$ olarak tespit edilmiştir. Bunun yanı sıra yer yer sıcaklık artışının $20^{\circ} \mathrm{C}^{\prime}$ ye kadar yükseldiği belirtilmiştir. Deliömerli yangını için yapılan analizler sonucunda ise, ortalama olarak $9^{\circ} \mathrm{C}$ olan yangın sonrası yer yüzey sıcaklığı artışının bazı konumlarda $18^{\circ} \mathrm{C}^{\prime}$ ye kadar çıktığı tespit edilmiştir. Bu iki çalışmanın ortalama sıcaklık artışı değerleri birbiri ile benzerlik göstermektedir. Sarp vd. (2018) tarafından yapılan bir başka çalışmada ise Yukarıkükür yangını öncesinde bölgedeki en yüksek sıcaklık değeri $37,0^{\circ} \mathrm{C}$ iken, yangın sonrasında en yüksek sıcaklık $49,8^{\circ} \mathrm{C}$ olarak tespit edilmiştir. Deliömerli yangını için yapılan çalışmalar sonucunda ise literatür çalışmasına benzer olarak, yangın bölgesinde yangın öncesinde tespit edilen en yüksek sicaklık değeri $38^{\circ} \mathrm{C}$ iken yangın sonrasında bu değer $50^{\circ} \mathrm{C}$ 'ye kadar yükseldiği görülmüştür.

Son olarak Deliömerli yangınında yangından hangi arazi kullanım sınıfının ne kadar etkilendiğinin tespiti için örtüşme analizi yapılmıştır. Piksel tabanlı kontrollü sınıflandırma işlemiyle tespit edilen yanan alanlar ve arazi kullanım haritası Arcmap üzerinde örtüştürülmüştür. Yapılan birleştirme sonucunda yanan alan sınırları içerisinde tarım alanlarının \%0,7, iğne yapraklı ormanların \%75,7, karışık ormanların \%4,2, bitki değişim alanlarının ise \%19,3 oranında bulunduğu tespit edilmiştir.

Dünyada sık sık karşımıza çıkan orman yangınları insan hayatını ciddi derecede etkilemekte hatta iklimlerin değişmesinde bile rol oynamaktadır. Yaşanan yangınlara karşı insanlık olarak yapılması gereken orman yangınlarının sebepleri üzerindeki etkimizi mümkün olduğunca azaltmak ve yaşanan yangınlara müdahale yöntemlerimizi gelişen teknoloji ile birlikte geliştirmektir. İnsanlar orman yangınları konusunda bilinçlendirilmeli ve bunun yanı sıra yangında zarar gören bölgeler tekrar ağaçlandırılmaya ve geri kazanılmaya çalışılmalıdır.

\section{Kaynaklar}

Akyürek Ö. (2020), Termal uzaktan algılama görüntüleri ile yüzey sıcaklıklarının belirlenmesi: Kocaeli örneği, Doğal Afetler ve Çevre Dergisi, 6(2), 377-390.

CORINE, (2018), Web, https://land.copernicus.eu/pan-european/corine-land-cover [Erişim 10 Ekim 2020].

Dereli M.A., (2019), Sentinel-2A uydu görüntüleri ile Giresun il merkezi için kısa dönem arazi örtüsü değişiminin belirlenmesi, Afyon Kocatepe Üniversitesi Fen ve Mühendislik Bilimleri Dergisi, 19(2), 361-368.

Erener A., Sarp G., (2017), Forest fire monitoring by using satellite images and information technology, ISFOR 2017 International Symposium on New Horizons in Forestry, 18-20 October. ISBN: 978-605-9454-17-9, pp: 142

Gürkan A., Salıcı A., Yıldırım K., Yıldırım M., (2016), Uzaktan algilama ve coğrafi bilgi sistemleri yardımıyla Mustafa Kemal Üniversitesi Tayfur Ata Sökmen yerleşkesinin alan kullanım/arazi örtülülüğünün belirlenmesi, Tekirdağ Ziraat Fakültesi Dergisi, 13(02), 144-150.

Mercan Ç., (2020), Yer yüzeyinin sıcaklığının termal uzaktan algılama görüntüleri ile araştırılması: Muşs ili örneği, Türkiye Uzaktan Algilama Dergisi, 2(2), 42-49.

Orhan O., Dadaser-Celik F., Ekercin S., (2019), Investigating land surface temperature changes using Landsat-5 data and real-time infrared thermometer measurements at Konya closed basin in Turkey, International Journal of Engineering and Geosciences, 4(1), 16-27.

Özdemir A.K., Tolun S., Demirci E., (2011), Endeks getirisi yönünün ikili sınfflandırma yöntemiyle tahmin edilmesi: IMKB-100 endeksi örneği, Niğde Üniversitesi, İBBF Dergisi, 4(2), 45-59. 
Polat N., (2020), Mardin ilinde uzun yıllar yer yüzey sıcaklı̆̆ı değişiminin incelenmesi, Türkiye Uzaktan Algılama Dergisi, 2(1), 1015.

Sabuncu A., Özener H., (2019), Uzaktan algılama teknikleri ile yanmış alanların tespiti: İzmir Seferihisar orman yangını örneği, Doğal Afetler ve Çevre Dergisi, 5(2), 317-326.

Sarp G., Temurçin K., Aldırmaz Y., Baydoğan E., (2018), Spatial analysis of forest fires using remote sensing technologies; a case of 2017 Mersin-Anamur forest fire, Innovation and Global Issues Congress IV, Antalya.

Taşdelen Ö., (2019), Yer yüzey sıcaklık haritalarının yerel ve ülke ölçeğinde zamansal ve mekânsal olarak uzaktan algılama ile tespiti, Yüksek Lisans Tezi, Kocaeli Üniversitesi, Kocaeli.

Taşdelen Ö., Erener A., (2019), Spatio-temporal determination of Land Surface Temperature (LST) by using remote sensing technologies, 4. International Conference on Civil Environmental, Geology and Mining Engineering (ICOCEM), 20-22 April, Trabzon, ss.1170-1176.

Tekeli A.E., Sönmez İ., Erdi E., Arslan M., Çukurçayır M.L., Demir F., (2007), Orman yangınlarının uzaktan algılama teknikleri ile tespit çalışmaları, TMMOB Afet Sempozyumu, TMMOB İnşaat Mühendisleri Odası, 5-7 Aralık, Ankara.

Yavuz M., Sağlam B., (2011), Uzaktan algılama ve coğrafi bilgi sistemlerinin orman yangınlarında kullanılması, 1. Ulusal Akdeniz Orman ve Çevre Sempozyumu, KSÜ Mühendislik Bil. Der., Özel Sayı, 2012, 235-242.

Yıldız A., Bağcı M., Başaran C., Çonkar F.E., Ayday C., (2017), Landsat-8 uydu verilerinin jeotermal saha araştırmalarında kullanılması: Gazlıgöl (Afyonkarahisar) çalışması, Afyon Kocatepe Üniversitesi Fen ve Mühendislik Bilimleri Dergisi, 17(4), 277284.

Vlassova L., Perez-Cabello F., Mımbrero M., Rodrigues L., Raquel M., Garcia-Martın A., (2014), Analysis of the relationship between land surface temperature and wildfire severity in a series of landsat images, Remote Sensing, ISSN 2072-4292.

Quintano C., Fernandez-Manso A., Calvo L., Marcos E., Valbuena M.L., (2014), Land surface temperature as potential indicator of burn severity in forest mediterranean ecosystems, International Journal of Applied Earth Observation and Geoinformation, 36, 112.

Zhang Y., (2002), Problems in the fusion of commercial high-resolution satellite as well as Landsat 7 images and initial solutions, International Archives of Photogrammetry Remote Sensing and Spatial Information Sciences, 34(4), 587-592. 